\title{
A new phenylethyl alkyl amide from the Ambrostoma quadriimpressum Motschulsky
}

\author{
Guolei Zhao, Chao Yang ${ }^{*}$, Bing Li and Wujiong Xia
}

\section{Full Research Paper}

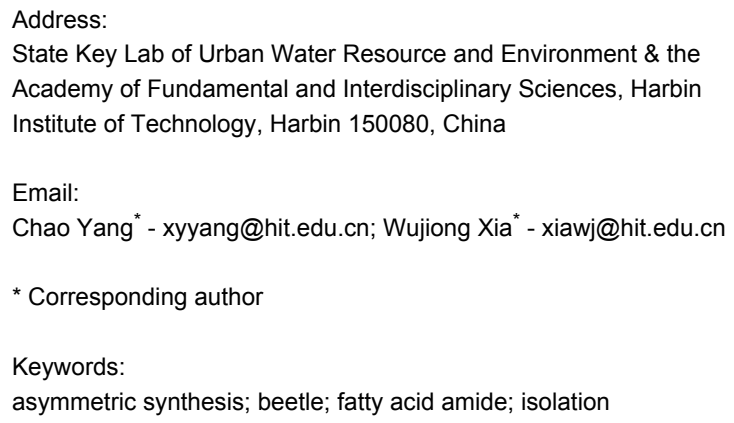

asymmetric synthesis; beetle; fatty acid amide; isolation

\begin{abstract}
A new phenylethyl alkyl amide, (10R)-10-hydroxy- $N$-phenethyloctadecanamide (1), was isolated from the beetle Ambrostoma quadriimpressum Motschulsky. The structure of the amide was determined by NMR and MS. The absolute configuration of compound 1 was confirmed by an asymmetric total synthesis, which was started from L-glutamic acid. The construction of the aliphatic chain was accomplished by the selective protection of the hydroxy groups and two-time implementation of the Wittig olefination reaction.
\end{abstract}

\section{Introduction}

The leaf beetle Ambrostoma quadriimpressum Motschulsky (Coleoptera: Chrysomelidae) is a serious pest of elm that exists primarily in north-eastern China. Adult beetles hibernate over the winter and emerge in the spring when their host plant is most succulent. The developmental stages of beetles are able to defend themselves against predatory attracks, and this defence is associated with chemical defensive compounds.

Insects are able to produce a vast array of biologically active secondary metabolites, which are used for defence purposes or as pheromones. In particular, the chemical defensive phenomenon of the beetle has been observed in Coleoptera [1,2]. Over the last few years, many research efforts have concentrated on chemical communication among beetles [3-6]. Only a limited number of semiochemicals [7-13] are known in leaf beetles. To the best of our knowledge, fatty acid amides from terrestrial insects have not been reported so far. In addition, certain marine organisms [14,15] and mushrooms [16,17] are the only two natural sources of phenylethyl alkyl amides with remarkable activities, such as cytotoxicity to murine leukemia cells (P-388) [14] and protective activity against endoplasmic reticulum stress-dependent cell death [17]. In the current study, we report the isolation of (10R)-10-hydroxy- $N$-phenethyloctadecanamide (1), a possible chemical defensive compound from the beetle $A$. quadriimpressum, and confirmation of its absolute configuration by total synthesis. 
Results and Discussion Isolation of (10R)-10-hydroxy- $N$-phenethyloctadecanamide (1)

Petroleum ether extracts from adult $A$. quadriimpressum were purified repeatedly by means of silica gel column chromatography. Compound 1 was obtained as a white solid. An ion peak at $m / z 403$ and an $\left[\mathrm{M}-\mathrm{H}_{2} \mathrm{O}\right]^{+}$peak at $m / z 385$ in the EIMS suggested the presence of an $\mathrm{OH}$ group. The molecular formula of 1 was confirmed as $\mathrm{C}_{26} \mathrm{H}_{45} \mathrm{NO}_{2}\left(\mathrm{~m} / z\right.$ 404.3529, $\left.[\mathrm{M}+\mathrm{H}]^{+}\right)$by HRMS-ESI analysis. The ${ }^{1} \mathrm{H}$ NMR spectrum showed aromatic protons $[\delta 7.33-7.18(\mathrm{~m}, 5 \mathrm{H})], \mathrm{CH}_{2}$ groups $[\delta 3.52(\mathrm{q}, J=6.4$ $\mathrm{Hz}, 2 \mathrm{H}), 2.82(\mathrm{t}, J=6.8 \mathrm{~Hz}, 2 \mathrm{H}), 2.11(\mathrm{t}, J=7.2 \mathrm{~Hz}, 2 \mathrm{H})$, $1.58-1.05(\mathrm{~m}, 24 \mathrm{H})]$, an amide proton $[\delta 5.39(\mathrm{br} \mathrm{s}, 1 \mathrm{H})]$, a $\mathrm{CH}$ group $[\delta 3.58(\mathrm{br} \mathrm{m}, 1 \mathrm{H})]$ and an Me group $[\delta 0.88(\mathrm{t}, J=6.8$ $\mathrm{Hz}, 3 \mathrm{H})]$. The COSY spectrum showed that compound $\mathbf{1}$ had a coupled proton spin system $\mathrm{CH}_{2} \mathrm{CH}_{2} \mathrm{NH}(\delta 5.39,3.52,2.82$ ppm). Correlations obtained from an HMBC spectrum provided partial evidence to assign a phenylethylamine moiety. The location of the $\mathrm{OH}$ group in the aliphatic chain was assigned by EIMS analysis; specifically, evidence was provided by a strong $[\mathrm{M}-113]^{+}$peak at $\mathrm{m} / \mathrm{z} 290$ corresponding to the loss of $\mathrm{C}_{8} \mathrm{H}_{17}$ (Scheme 1). Hence, compound 1 was confirmed as 10-hydroxy$N$-phenethyloctadecanamide. In addition, compound 1 showed positive optical rotation $\left([\alpha]^{20}{ }_{\mathrm{D}}+38.5\left(c 0.13, \mathrm{CHCl}_{3}\right)\right)$. To confirm the absolute configuration at $\mathrm{C}_{(10)}$, an asymmetric total synthesis was performed.

\section{Synthesis of (10R)-10-hydroxy- $N$-phenethyl- octadecanamide (1)}

The retrosynthetic analysis of compound $\mathbf{1}$ is outlined in Scheme 2. The target molecule is disconnected into two fragments, $\mathbf{2}$ and $\mathbf{3}$. The intermediate fragment $\mathbf{2}$ would be readily

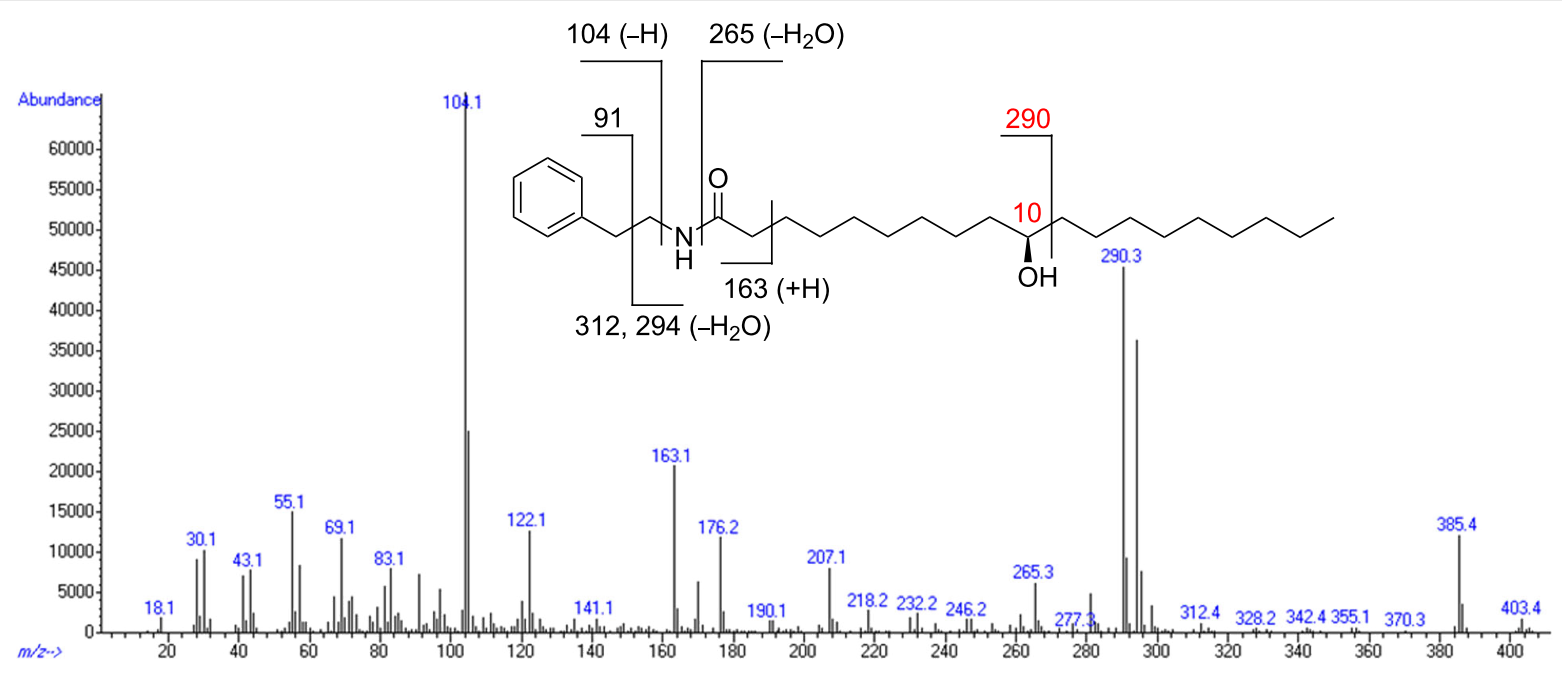

Scheme 1: Chemical structure of compound 1 and mass spectral analysis.

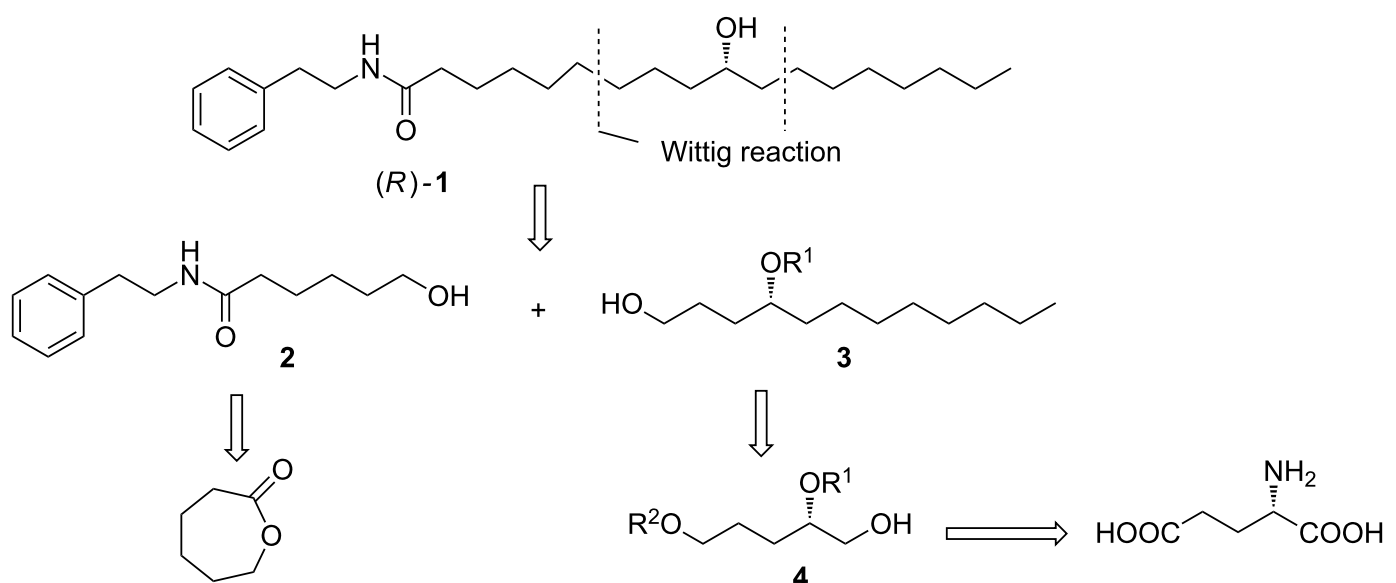




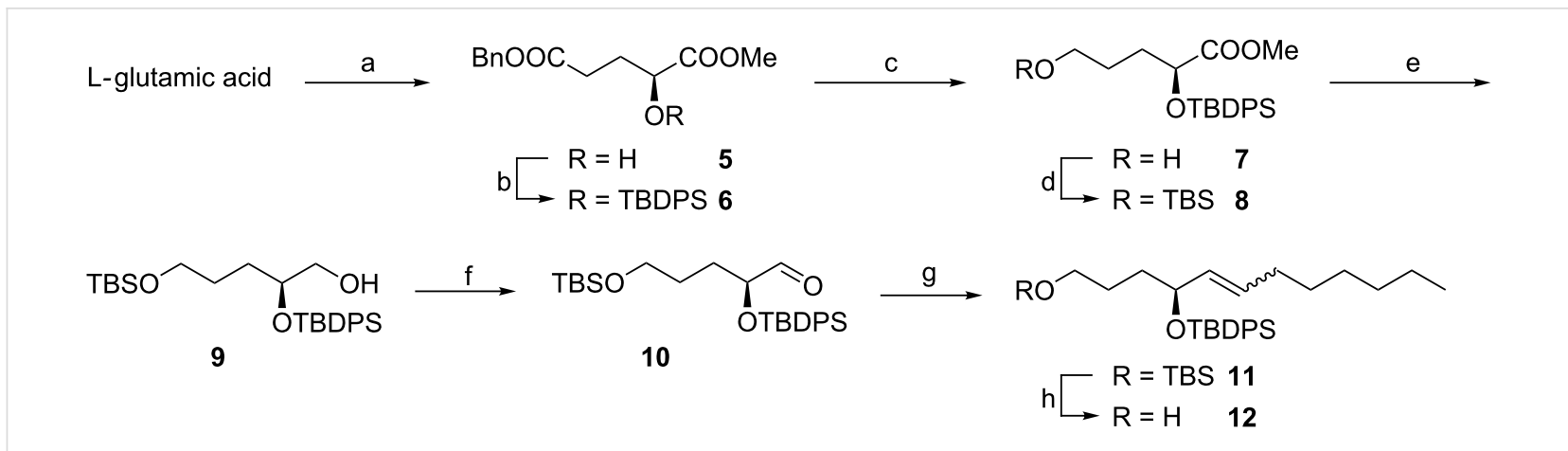

Scheme 3: (a) BnOH, $\mathrm{H}_{2} \mathrm{SO}_{4} ; \mathrm{NaNO}_{2}, \mathrm{AcOH} ; \mathrm{CH}_{2} \mathrm{~N}_{2}, 35 \%$ in 3 steps. (b) TBDPSCl, imidazole, $100 \%$. (c) $\mathrm{Pd} / \mathrm{C}, \mathrm{H}_{2} ; \mathrm{BH} \cdot \mathrm{THF}, 95 \%$ in 2 steps. (d) TBDMSCl, imidazole, $100 \%$. (e) Dibal-H, $86 \%$. (f) PCC, 94\%. (g) $\mathrm{C}_{7} \mathrm{H}_{15} \mathrm{PPh}_{3} \mathrm{Br}, n-\mathrm{BuLi}, 75 \%$. (h) $\mathrm{PPTS}, 98 \%$.

prepared from the commercially available $\varepsilon$-caprolactone. The crucial fragment 3 would be constructed from the intermediate 4 through Wittig olefination. The polyhydroxy compound 4 would be obtained from L-glutamic acid by selective protection.

Our synthesis started from the ready available L-glutamic acid, as shown in Scheme 3. On the basis of the preceding literature [18-20], the hydroxy diester 5 was obtained in 35\% yield ( $\mathrm{BnOH}, \mathrm{H}_{2} \mathrm{SO}_{4} ; \mathrm{NaNO}_{2}, \mathrm{AcOH} ; \mathrm{CH}_{2} \mathrm{~N}_{2}$ ). Protection of the secondary alcohol with the TBDPS group gave compound $\mathbf{6}$ in quantitative yield. The following debenzylation and reduction with $\mathrm{BH}_{3}$.THF afforded alcohol 7 in 95\% isolated yield. Then primary alcohol 7 was protected again with TBDMSCl to give compound 8 in $100 \%$ yield. An initial attempt to synthesize compound 9 by reduction of $\mathbf{8}$ with $\mathrm{LiAlH}_{4}$, however, resulted in the deprotection of the TBDPS group. Alternatively, the alcohol 9 could be obtained by reduction with diisobutylaluminium hydride (Dibal-H) in $86 \%$ yield, which was then converted to the corresponding aldehyde $\mathbf{1 0}$ by oxidation with PCC. Wittig olefination of aldehyde $\mathbf{1 0}$ with $n$-heptylidenetriphenylphosphonium bromide in the presence of $n$-BuLi gave adduct 11 as an $(E / Z)$-mixture $(E / Z=1: 5)$ in $75 \%$ yield. Selec- tive removal of the TBS group with pyridinium tosylate gave $\mathbf{1 2}$ in $98 \%$ yield [21].

With the alcohol 12 in hand, our next step was to synthesize the phosphonium salt 15 [22,23] (Scheme 4). Therefore, $\varepsilon$-caprolactone was hydrolyzed with $5 \% \mathrm{NaOH}$ to give hydroxy acid $\mathbf{1 3}$ in quantitative yield, which was reacted with $\mathrm{PBr}_{3}$ in $\mathrm{CH}_{2} \mathrm{Cl}_{2}$ to afford compound 14 in $82 \%$ yield. Treatment of 14 with $\mathrm{PPh}_{3}$ in $\mathrm{CH}_{3} \mathrm{CN}$ gave the phosphonium salt $\mathbf{1 5}$ in $98 \%$ yield.

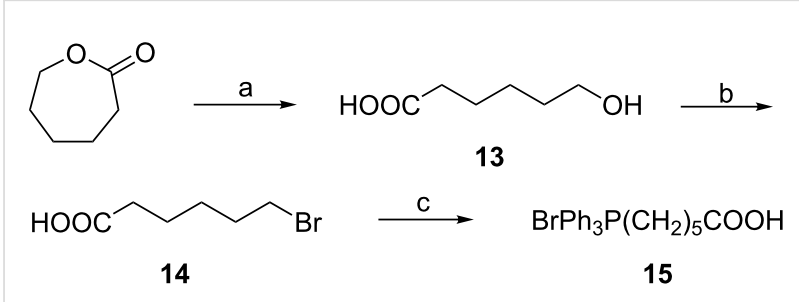

Scheme 4: (a) $5 \% \mathrm{NaOH}, 100 \%$. (b) $\mathrm{PBr}_{3}, 82 \%$. (c) $\mathrm{PPh}_{3}, 98 \%$.

The construction of the aliphatic chain was achieved according to the synthetic plan shown in Scheme 5. Oxidation of the

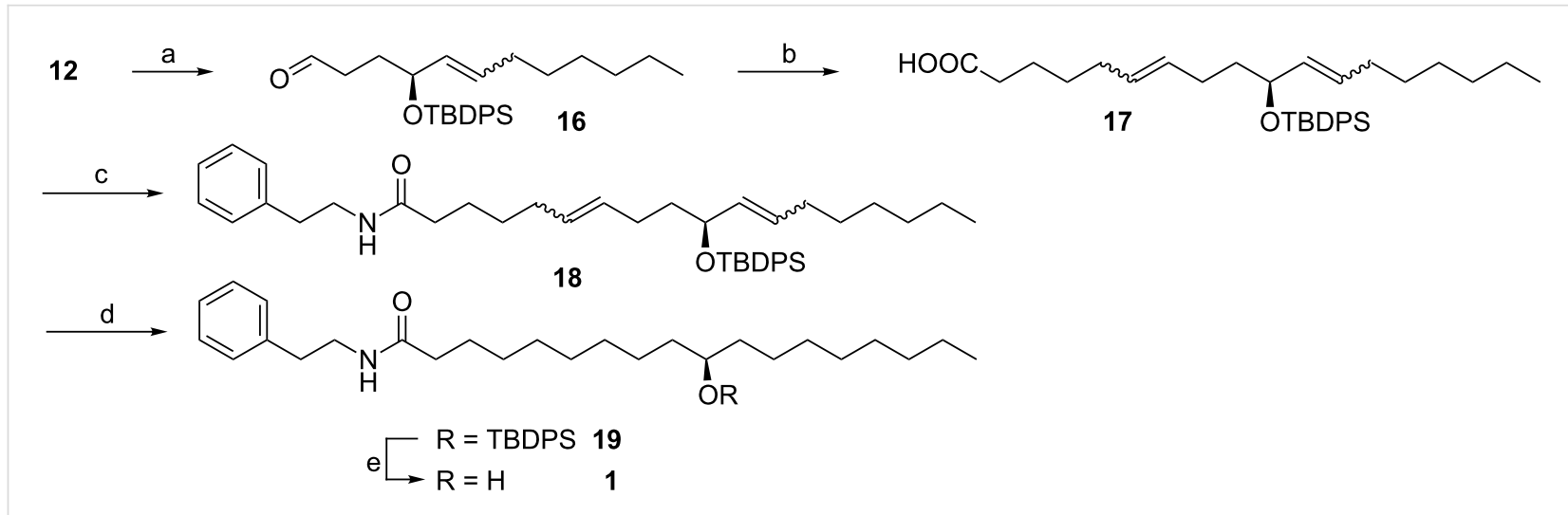

Scheme 5: (a) PCC, 96\%. (b) LDA, 15, 72\%. (c) DCC, DMAP, phenylethylamine, $80 \%$. (d) Pd/C, $\mathrm{H}_{2}, 100 \%$. (e) TBAF, $93 \%$. 
alcohol 12 with PCC afforded the corresponding aldehyde 16, followed by a Wittig reaction with salt $\mathbf{1 5}$ in the presence of two equiv LDA, which afforded the adduct $\mathbf{1 7}$ as an $(E / Z)$-mixture in $72 \%$ yield. The $E / Z$ isomers of $\mathbf{1 7}$ were not separated because the olefin geometry has no effect on the synthesis. Therefore, compound 17 was directly converted to the amide 18 with DCC and DMAP in $80 \%$ yield. Reduction of the $\mathrm{C}=\mathrm{C}$ double bond by hydrogenation with $\mathrm{Pd} / \mathrm{C}$ gave compound 19 in quantitative yield, which was transferred to the final product $(R)-1$ in $93 \%$ yield by removal of the TBDPS group. Both NMR and EIMS data were in complete agreement with those of the natural product $\mathbf{1}$. In addition, the synthetic compound $(R)-\mathbf{1}$ showed positive optical rotation $\left([\alpha]^{20}{ }_{\mathrm{D}}+37.2\left(c 0.85, \mathrm{CHCl}_{3}\right)\right)$, suggesting that the absolute configuration of natural product $\mathbf{1}$ is to be assigned $(R)$.

\section{Conclusion}

In summary, a new natural product, (10R)-10-hydroxy- $N$ phenethyloctadecanamide (1) from Ambrostoma quadriimpressum Motschulsky was identified and synthesized. Further studies on the biological roles of fatty acid amides are currently being performed by our group.

\section{Experimental}

General Methods: Commercial, spectral-grade solvents were used for the experiments unless otherwise stated. Infrared spectra were recorded on a Perkin-Elmer 1710 Fourier transform spectrometer. Low-resolution mass spectra were obtained from Agilent 7890A-5975C GC-MS by means of electron impact (EI) ionization at $70 \mathrm{eV} .{ }^{1} \mathrm{H}$ NMR spectra were obtained at $400 \mathrm{MHz}$ on a Bruker AV-400 instrument. ${ }^{13} \mathrm{C}$ NMR spectra were recorded at $100 \mathrm{MHz}$. High-resolution mass spectra were recorded on an Agilent 1200-6520 Q-TOF electrospray mass spectrometer.

\section{Isolation of (10R)-10-hydroxy- $N$-phenethyl- octadecanamide (1)}

Approximately 3000 adult $A$. quadriimpressum were extracted with petroleum ether. The combined extract was filtered and vacuum dried on a rotary evaporator to give a thick paste (18 $\mathrm{g}$ ). Flash chromatographic (FC) separation of this extract on a silica gel column with $100 \% \rightarrow 0 \% \mathrm{PE} / \mathrm{AcOEt}$ gave five fractions. Fraction 4 was further separated into seven fractions on a silica gel column (PE/AcOEt 10:1 $\rightarrow 1: 1$ ). GC-MS analysis showed that fractions 4-4 and 4-5 included derivatives of a fatty acid amide. Fraction 4-5 was further purified by crystallization in diethyl ether to yield compound $\mathbf{1}(3 \mathrm{mg}$ ) as a white solid. $\mathrm{Mp}$ $107{ }^{\circ} \mathrm{C}\left(\mathrm{Et}_{2} \mathrm{O}\right) ;[\alpha]^{20}{ }_{\mathrm{D}}+38.5\left(c 0.13, \mathrm{CHCl}_{3}\right)$; IR (KBr) $v_{\max }$ : 3312, 2920, 2846, 1643, $1554 \mathrm{~cm}^{-1}$; ${ }^{1} \mathrm{H}$ NMR (400 MHz, $\left.\mathrm{CDCl}_{3}\right) \delta 7.32(\mathrm{t}, J=7.6 \mathrm{~Hz}, 2 \mathrm{H}), 7.22(\mathrm{~d}, J=7.6 \mathrm{~Hz}, 1 \mathrm{H}), 7.19$ (t, $J=7.6 \mathrm{~Hz}, 2 \mathrm{H}), 5.39$ (br s, 1H), 3.58 (br m, 1H), 3.52 (q, $J=$
$6.4 \mathrm{~Hz}, 2 \mathrm{H}), 2.82(\mathrm{t}, J=6.8 \mathrm{~Hz}, 2 \mathrm{H}), 2.11(\mathrm{t}, J=7.2 \mathrm{~Hz}, 2 \mathrm{H})$, $1.58-1.05(\mathrm{~m}, 24 \mathrm{H}), 0.88(\mathrm{t}, J=6.8 \mathrm{~Hz}, 3 \mathrm{H}) ;{ }^{13} \mathrm{C} \mathrm{NMR}(100$ $\left.\mathrm{MHz}, \mathrm{CDCl}_{3}\right) \delta 173.1,139.0,128.8,128.6,126.5,72.0,40.5$, $37.5,37.5,36.8,35.7,31.9,29.7,29.6,29.4,29.3,29.2,25.7$, 25.6, 22.7, 14.1; EIMS (m/z): 403, 385, 294, 290, 265, 176, 163 , 122, 104 (base), 91, 83, 69, 55, 43; HRMS-ESI $(\mathrm{m} / \mathrm{z})$ : $[\mathrm{M}+\mathrm{H}]^{+}$ calcd for $\mathrm{C}_{26} \mathrm{H}_{45} \mathrm{NO}_{2}$, 404.3529; found, 404.3529.

\section{Supporting Information}

\section{Supporting Information File 1}

Detailed experimental procedures for the synthesis of compound $\mathbf{1}$.

[http://www.beilstein-journals.org/bjoc/content/ supplementary/1860-5397-7-158-S1.pdf]

\section{Acknowledgements}

We are grateful for the financial supports from China NSFC (Nos. 20802013, 21002018 and 21072038), HIT.NSRIF (Nos. 01107866 and 01107986), the Fundamental Research Funds for the Central Universities (No. HIT.BRET2.2010001) and Wenzhou Science and Technology Program (No.G20100056).

\section{References}

1. Duffey, S. S. Annu. Rev. Entomol. 1980, 25, 447-477. doi:10.1146/annurev.en.25.010180.002311

2. Burse, A.; Frick, S.; Discher, S.; Tolzin-Banasch, K.; Kirsch, R.; Strauß, A.; Kunert, M.; Boland, W. Phytochemistry 2009, 70, 1899-1909. doi:10.1016/j.phytochem.2009.08.002

3. Visser, J. H.; van Straten, S.; Maarse, H. J. Chem. Ecol. 1979, 5, 13-25. doi:10.1007/BF00987684

4. Pasteels, J. M.; Dobler, S.; Rowell-Rahier, M.; Ehmke, A.; Hartmann, T. J. Chem. Ecol. 1995, 21, 1163-1179. doi:10.1007/BF02228318

5. Termonia, A.; Pasteels, J. M. Chemoecology 1999, 9, 13-23. doi:10.1007/s000490050029

6. Wegener, R.; Schulz, S.; Meiners, T.; Hadwich, K.; Hilker, M. J. Chem. Ecol. 2001, 27, 499-515. doi:10.1023/A:1010397107740

7. Schulz, S.; Gross, J.; Hilker, M. Tetrahedron 1997, 53, 9203-9212. doi:10.1016/S0040-4020(97)00618-2

8. Pasteels, J. M.; Rowell-Rahier, M.; Braekman, J. C.; Dupont, A. Physiol. Entomol. 1983, 8, 307-314. doi:10.1111/j.1365-3032.1983.tb00362.x

9. Pasteels, J. M.; Duffey, S.; Rowell-Rahier, M. J. Chem. Ecol. 1990, 16, 211-222. doi:10.1007/BF01021280

10. Willinger, G.; Dobler, S. Biochem. Syst. Ecol. 2001, 29, 335-346. doi:10.1016/S0305-1978(00)00082-X

11. Laurent, P.; Dooms, C.; Braekman, J.-C.; Daloze, D.; Habib-Jiwan, J.-L.; Rozenberg, R.; Termonia, A.; Pasteels, J. M. Naturwissenschaften 2003, 90, 524-527. doi:10.1007/s00114-003-0471-y

12. Gillespie, J. J.; Kjer, K. M.; Duckett, C. N.; Tallamy, D. W. Mol. Phylogenet. Evol. 2003, 29, 161-175. doi:10.1016/S1055-7903(03)00256-2

13. Hartmann, T. Planta 2004, 219, 1-4. doi:10.1007/s00425-004-1249-y 
14. Liyanage, G. K.; Schmitz, F. J. J. Nat. Prod. 1996, 59, 148-151. doi:10.1021/np960032t

15. Böröczky, K.; Laatsch, H.; Wagner-Döbler, I.; Stritzke, K.; Schulz, S. Chem. Biodiversity 2006, 3, 622-634. doi:10.1002/cbdv.200690065

16. Shiono, Y.; Tamesada, Y.; Muravayev, Y. D.; Murayama, T.; Ikeda, M. Nat. Prod. Res. 2005, 19, 363-366. doi:10.1080/14786410412331280113

17. Choi, J.-H.; Maeda, K.; Nagai, K.; Harada, E.; Kawade, M.; Hirai, H.; Kawagishi, H. Org. Lett. 2010, 12, 5012-5015. doi:10.1021/ol102186p

18. Civitello, E. R.; Rapoport, H. J. Org. Chem. 1994, 59, 3775-3782. doi:10.1021/jo00093a008

19. Liu, R.-C.; Huang, W.; Ma, J.-Y.; Wei, B.-G.; Lin, G.-Q. Tetrahedron Lett. 2009, 50, 4046-4049. doi:10.1016/j.tetlet.2009.04.097

20. Qabar, M. N.; Kahn, M. Tetrahedron Lett. 1996, 37, 965-968. doi:10.1016/0040-4039(95)02340-2

21. Andreou, T.; Costa, A. M.; Esteban, L.; Gonzàlez, L.; Mas, G.; Vilarrasa, J. Org. Lett. 2005, 7, 4083-4086. doi:10.1021/ol051200o

22. Sankaranarayanan, S.; Chattopadhyay, S. Tetrahedron: Asymmetry 1998, 9, 1345-1350. doi:10.1016/S0957-4166(98)00091-3

23. Nanda, S.; Yadav, J. S. Tetrahedron: Asymmetry 2003, 14 , 1799-1806. doi:10.1016/S0957-4166(03)00369-0

\section{License and Terms}

This is an Open Access article under the terms of the Creative Commons Attribution License

(http://creativecommons.org/licenses/by/2.0), which permits unrestricted use, distribution, and reproduction in any medium, provided the original work is properly cited.

The license is subject to the Beilstein Journal of Organic Chemistry terms and conditions:

(http://www.beilstein-journals.org/bjoc)

The definitive version of this article is the electronic one which can be found at: doi:10.3762/bjoc. 7.158 